\section{Jurnal Hukum Volkgeist \\ Volume 5 Issue 1, Desember 2020 \\ P-ISSN : 2528-360X, E-ISSN : 2621-6159}

Huки

Mimbar Pendidikan Hukum Nasional

\title{
Mechanism for collective property sharing in mixed marriage
}

\author{
Siti Alafisyahrin Lasori ${ }^{1}$
}

\begin{abstract}
This research discusses the mechanism of sharing joint assets for mixed marriage partners. The results of the study illustrate the applicable provisions with the facts that occur in the community regarding land ownership for Indonesian husbands or wives in mixed marriages. The research method used in this research is normative research method. The statutory approach and the conceptual approach The statutory approach is an approach using legislation and regulations. And the conceptual approach is to refer to legal principles. These principles can be found in scholarly views or legal doctrines. This study aims to analyze the mechanism for sharing joint assets in marriage, is based on the prevailing laws and regulations and provides legal certainty for the husband or wife of Indonesian citizens regarding the status of land ownership in joint assets for mixed marriages. Based on the results of the research, a conclusion is obtained that land ownership for Indonesian citizens due to mixed marriages without being equated with land rights for their foreign partners, which is only limited to use rights. Legal certainty for current Indonesian citizens to be entitled to land with ownership rights.
\end{abstract}

Keywords: Mechanism, Joint Assets, Mixed Marriage

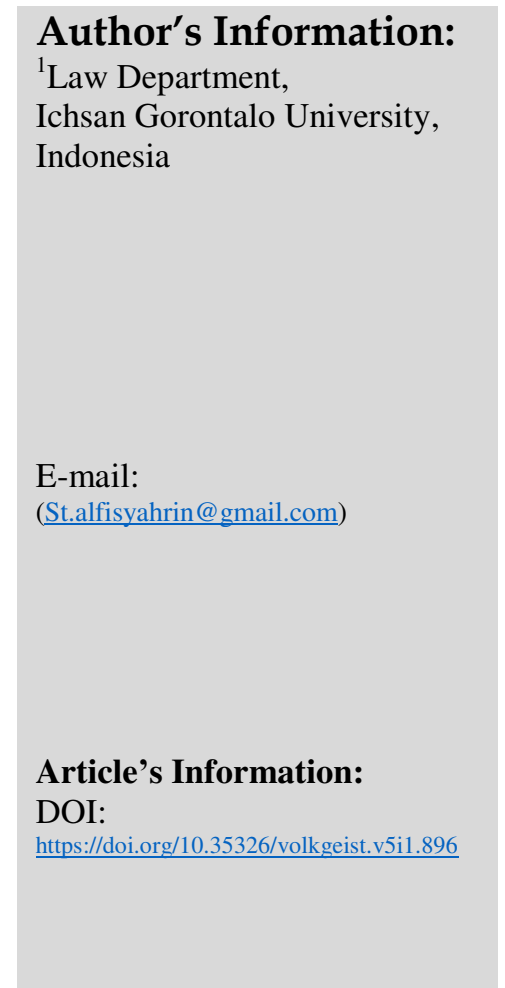

\section{Introduction}

In Indonesia, mixed marriage is a familiar phenomenon. In the history of the nation's founders, this mixed marriage has been going on in Indonesia for a long time. Starting with a trade mission, until finally it produced offspring known as Indo Chinese, Indo Arabic , Indo Dutch, almost part of Indonesian society is now not purely indigenous but has mixed with other countries.(Ratulangi, n.d.)

In Article 57 of Law No. 1 of 1974 on Marriage is stated that: "The definition of a mixed marriage is a marriage between two people who exist in Indonesia and subject to a different law, because of differences in nationality and one of the parties of Indonesian nationality, while the element -The elements contained in a mixed marriage, namely (Undang-Undang Nomor 12 Tahun 2006, n.d.): 1) Marriage that is conducted in the jurisdiction of Indonesia; 2) Each is subject to different laws because of different nationalities and one of the parties is Indonesian citizenship.

Furthermore, with the occurrence of mixed marriages, several problems will arise due to the occurrence of marriage, namely related to the legal consequences of marriage, among others, the result of marriage to husband and wife, the result of marriage on assets, and the consequences of marriage to children. Especially on a result of marriage teradap property, raised their innate property and joint property. Congenital assets are assets controlled by their respective owners, namely husband or wife. And each husband and wife has the full right to take legal actions against their property. This 
is as regulated in article 36 paragraph 2 of Law Number 1 Year 1974 concerning marriage. While joint assets are assets controlled by husband and wife, husband or wife can act on joint assets with the consent of both parties. In Article 36 paragraph 1 of Law Number 1 Year 1974 concerning Marriage, it is regulated on this matter . Joint assets husband and wife have the same rights and obligations.

Furthermore, it is reaffirmed in Article 35 paragraph 1 and 2 of Law Number 1 of 1974 concerning Marriage which reads "Paragraph (1) Assets acquired during marriage become joint assets. (Paragraph 2) The inheritance of each husband and wife and the property obtained by each as a gift or inheritance is under their respective control as long as the parties do not determine otherwise.

In Article 21 paragraph (3) UUPA it is stated that: "Foreigners who after the enactment of this law obtain property rights due to inheritance without a will or a mixture of assets due to marriage, likewise Indonesian citizens who have property rights and after this Law is enacted lose their citizenship are obliged to relinquish this right within the period of time.(Undang-Undang Nomor 5 Tahun 1960 tentang PeraturanPeraturan Dasar Pokok Agraria, n.d.) 1 (one) year after the right was obtained or the citizenship was lost. If in the past period, the ownership rights are not released, then the right is canceled because the law and land fall to the state, provided that the rights of the other party continue to impose them.

Indonesian citizens should still apply the rules contained in Article 21 paragraph (1), namely "only Indonesian citizens have the right to property rights". In Article 21 paragraph (1) of the above-mentioned Law, it is clear that every Indonesian citizen without exception is entitled to land with the status of ownership rights. However, in reality, land rights with ownership rights for Indonesian citizens in mixed marriages are strongly influenced by the existence of a marriage agreement.(Undang-Undang Nomor 5 Tahun 1960 tentang Peraturan-Peraturan Dasar Pokok Agraria, n.d.)

The point of the problem in the occurrence of a divorce is joint property. The Marriage Law (Article 37) only states that if the marriage breaks up due to divorce, joint assets are regulated according to their respective laws. In the explanation of the $\mathrm{P}$ origin of the states that is "legal" respectively mean religious law, customary law, and the law - other laws. If we look at the legal system as mentioned earlier, the settlement for this collective property can be determined as follows: For those who are married according to Islam, it must be distributed according to Islamic law which refers to the compilation of Islamic law. So if referring to this legal basis, the legal consequences of mixed marriages are based on the chronology of the case below, so for Indonesian citizens who are married to foreign citizens, it will be difficult to own land or buildings with property rights status .

Because couples in mixed marriages feel aggrieved by a number of provisions in the UUPA and the Marriage Law. Foreign nationals who are married to Indonesians cannot have rights to land, let alone share assets after the break-up of the marriage. As a result, mixed marriage couples feel disadvantaged by Law Number 5 of 1960 concerning Basic Agrarian Regulations (UUPA) and Law Number 1 of 1974 concerning Marriage (UUP).

He considered that Article 21 paragraph (1) and Article 36 paragraph (1) of the UUPA have different meanings from what the 1945 Constitution aspires to. The problem is, the phrase "WNI" is interpreted as "Indonesian citizens who are not married or Indonesian citizens who are married to other Indonesians ". , the fact is that many 
Indonesian citizens marry foreigners, but still retain Indonesian citizenship and live permanently in Indonesia. Indonesian citizens who are married to foreigners do not lose their citizenship, they remain as Indonesian citizens who have the same rights as other Indonesian citizens. There is not a single law which states that there is a difference between the citizenship status of Indonesian citizens who are married to foreigners as stipulated in Article 2 of Law Number 12 of 2006 concerning Citizenship.

\section{Research Methods}

In this study, researchers used this type of approach Legislation according to Peter Mahmud Marzuki "The statute approach is carried out by examining all laws and regulations related to the legal issue being handled. The statutory approach is an approach using legislation and regulations ".(Marzuki, 2010). As the type of research used is normative legal research. The technique of collecting legal materials used in this research is none other than those stated by Mukti Fajar and Yulianto Achmad that: "Data collection techniques in normative legal research are carried out by literature study of legal materials, both primary legal materials, secondary legal materials, as well as tertiary legal materials.(Achmad, n.d.) The analysis technique used is descriptiveanalysis, namely a simple description of a condition or position of legal or non - legal propositions .

\section{Result and Discussion}

\subsection{The Mechanism of Mixed Marriage in Indonesia on Joint Property Ownership for Indonesians in Marriage}

In BW Indonesia's civil law, namely recognizing the sharing of joint assets in the event of a divorce, this joint property is divided into two and each gets half of the assets. Whereas for those who are subject to the Civil Code, in the event of a divorce, the joint property is divided into two between the husband and ex-wife files. In a mixed marriage, again it must be seen which law they agree to use by seeing how the marriage is carried out. Because it is related to foreigners who have a different legal system, it is better if in a mixed marriage it should be carried out through proper legal procedures in accordance with the prevailing laws and regulations and as far as possible be accompanied by a marriage agreement concerning the status of assets in the marriage later. . Thus, legal certainty in an undertaken marriage can be more secure for all parties.(Manan, 2006)

Seeing the above explanation, of course, these assets stand alone even in a divorce like that the husband's property belongs to the husband and the wife's property belongs to the wife when they are divorced, but when they are not divorced, Indonesian law does not allow joint assets. for the perpetrators of these mixed marriages certainly makes some people menggangap discrimination against foreigners with the law in Indonesia.

\section{a. The Mechanism of Mixed Marriage between Indonesian Citizens and Foreigners in Indonesia}

Currently, there are many Indonesians who intend to have mixed marriages (marriages with different nationalities) but are constrained or at least lack of information on this. Therefore, in the following research, the researcher provides other basic information regarding matters related to mixed marriages, especially for Indonesian citizens (WNI) who are going to marry in Indonesia to male foreign citizens (WNA) 
based on the current law. this (Law No. 1 of 1974 concerning Marriage).(UU Nomor 1 Tahun 1974 Tentang Perkawinan, n.d.)

\section{Mixed Marriage}

Marriage between two people who in Indonesia are subject to different laws, due to differences in nationality, is known as Mixed Marriage (Article 57 of Law No.1 of 1974 concerning Marriage). This means that the marriage that you will do is a mixed marriage. ${ }^{16}$

\section{In accordance with the Applicable Law}

Mixed marriages that are held in Indonesia are carried out according to Marriage Law and must fulfill the conditions of marriage. Marriage requirements include: there is an agreement between the two prospective brides, permission from both parents / guardians for those who are not yet 21 years old, and as well (see article 6 of the Marriage Law).(UU Nomor 1 Tahun 1974 Tentang Perkawinan, n.d.)

\section{Certificate of Marriage Registration Officer}

If all the conditions have been met, you can ask the marriage registrar to provide a certificate from the marriage registrar of each party, - you and your future husband, (article 60 paragraph 1 of the Marriage Law). This certificate contains information that it is true that the conditions have been met and there are no obstacles to getting married. If the marriage registrar refuses to provide a certificate, then it can ask the Court to issue a Decree, stating that the rejection is unwarranted (article 60 paragraph 3 of the Marriage Law), this Certificate or Decree in lieu of Information is valid for six months. If during that time, the marriage has not been carried out, then the Certificate or Decree will no longer have power (article 60 paragraph 5 of the Marriage Law).

\section{The papers to prepare}

There are several other letters that must also be prepared, namely:

\section{a. For future husbands}

You must ask your future husband to complete the papers from his area or country of origin. To be able to get married in Indonesia, he must also submit a "Certificate" stating that he can marry and will marry an Indonesian citizen. This decree is issued by the competent authority in the country. In addition, it must also be attached:

a) Photocopy of Personal Identity (KTP / passport );

b) Photocopy of Birth Certificate;

c) Certificate that he is not currently married; or Divorce Certificate if ever married; or the wife's death certificate if the wife dies. These letters are then translated into Indonesian by a translator who is sworn in and then must be legalized by the foreign national embassy in Indonesia.

b. For the prospective wife, you must equip yourself with:

a) Photocopy of KTP;

b) Photocopy of Birth Certificate;

c) Data on the parents of the prospective bride and groom A cover letter from the RT RW stating that you have no obstacle for you to get married 
d) Marriage Registration (Article 61 paragraph 1 of the Marriage Law)

This marriage registration is intended to obtain a marriage certificate (excerpt from a marriage book) by authorized employees. For those who are Muslim, the recording is carried out by the employee of the marriage registrar or the assistant to the registrar of divorce divorces. As for non-Muslims, the recording is carried out by Civil Registry Officers.

\section{Legalize Marriage Certificate Quotes}

The excerpt from the Marriage Certificate that you have obtained, still has to be legalized at the Ministry of Law and Human Rights and the Ministry of Foreign Affairs, and registered at the embassy in the country of origin of your husband. With this legalization, your marriage is legal and accepted internationally, both for the law in the country of origin. husband, as well as according to Indonesian law

\section{a. Legal Consequences}

There are several consequences that you must accept if you marry a foreigner. One of the most important is related to the status of children. Based on the latest Citizenship Law, children born from the marriage of an Indonesian woman to a foreign man, as well as children born from the marriage of a foreign woman to an Indonesian citizen, are now both recognized as Indonesian citizens. The child will have dual nationality, and after the child is 18 years old or already married, he must make his choice. The statement to vote must be submitted no later than 3 (three) years after the child turns 18 years old or after marriage. So be prepared to take care of the procedure for selecting citizenship for mixed marriages that take place outside Indonesia, it must be registered at the Civil Registry office no later than 1 (one) year after the person concerned returns to Indonesia. If not, then your marriage has not been recognized by our laws. The proof of marriage is registered at the Marriage Registration Office where you live in Indonesia (article 56 paragraph (2) Law No. 1/74).

Based on an interview with Drs. Syamsudin Ibrahim as head of the Gorontalo city population service_which the researcher has made as a resource person that according to Mr. Syamsudin's observations at the civil registry office, there is nothing more specific about the distribution of joint assets for perpetrators of mixed marriages. so that the data in the civil registry office is not yet complete and the government needs to be updated again regarding the distribution of joint assets.

The law that must be used in the sharing of joint assets is Islamic law which is more precisely using the Law in the Compilation of Islamic Law and in Islamic law does not recognize the mixing of personal assets into the form of joint assets but it is recommended that there is mutual understanding between husband and wife in managing assets. personal, do not let this management cause damage to the relationship resulting in divorce.

Regarding Mixed Marriage, based on the perspective of the Koran, Islam does not recognize mixed marriage, because the position of fellow Muslims is the same and a noble person is in the sight of Allah SWT. The measure is to show devotion and obedience to Allah, not based on territorial or national boundaries. As contained in the Koran surah al- Hujuraat (49) verse 13 which

Meaning: 
O people, verily We created you from a man and a woman and made you nations and tribes so that you could know each other. Verily the noblest among you hand of God is the most pious among you. Verily, Allah knows the Most Get to know . \{ QS. Al-Hujurat (49 ): 13\}

Regarding the property rights of Indonesian citizens which are based on Law Number 5 of 1960 concerning Agrarian Principles, which is approximately 40 years old, it is felt that it is very necessary to undergo changes, because it is no longer in accordance with developments that occur in society. According to the Advisor for the Forum for Land Study and Consultation (FKKP) Chairul Basri, land ownership rights are attached to the subject of the owner. If the subject is an Indonesian citizen, then he / she has the right to own ownership rights. Meanwhile, his foreign partner as a foreign subject is only entitled to have the right to use. (Indonesia, n.d.)

Indonesian citizens who carry out mixed marriages without a marriage agreement should still be entitled to land with ownership rights, as long as they do not give up their citizenship (remain Indonesian citizens). Although there is joint ownership of land with ownership rights in a mixed marriage without a marriage agreement, the status of the land rights should be separated. Indonesian citizens are still entitled to land with ownership rights, while foreign spouses are only entitled to land with usufruct status. Indeed there are difficulties in understanding of Article 21 paragraph (3) Act - Act No. 5 of 1960. The solution, expected to be briefed in the future of our society (socialization) of the Act in force in Indonesia so as Indonesian citizens are no longer violated rights it's rights and our society is smarter about the law.

\subsection{Regulation on the distribution of joint assets in mixed marriages.}

Having opened up relations with the outside world, nowadays many foreigners live in Indonesia. They generally stay because they work, do business, or live temporarily as tourists to spend their holidays or as sometimes deliberately brought in by the State which is to be used as an asset for the country, this often happens as well, as is known most in the world of sports, especially in football. a ball that people often refer to as a transfer player. Therefore, it is commonplace if there is a marriage between them and Indonesian citizens. Maybe it does not matter if their marriage can run permanently according to the purpose of a marriage as it is referred to in the Marriage Law, namely the formation of a happy and eternal family / household based on the One Godhead. However, it will be a problem for the parties if there is a divorce, especially regarding the position of the child and the distribution of marital assets. Marriages between Indonesian citizens and foreigners in Indonesian law are called mixed marriages, namely marriages between two people who in Indonesia are subject to different laws due to differences in nationality and one of them is Indonesian citizenship (Article 57 UUP). This marriage is carried out in Indonesia, so in this mixed marriage, one of the parties can obtain the citizenship of the husband / wife and can also lose his citizenship according to the methods stipulated in the applicable Indonesian Citizenship Law.(Tutik, 2006)

Mixed Marriage according to Law no. 1 of 1974 is what is meant by mixed marriage in this Law, which is a marriage between two people who in Indonesia are subject to different laws, due to differences in nationality and one of the parties is a foreign citizen and one of the parties is an Indonesian citizen.(UU Nomor 1 Tahun 1974 Tentang Perkawinan, n.d.)

a. Article 38 of Law No. 1 of 1974 explains that a marriage can break up because: 
b. Death, the death of a person is a symptom of nature as the nature of a living being because death is unavoidable and is something that causes the break of the marriage of the husband and wife concerned.(Darmabrata, 2004)

c. Divorce, Article 14 of Government Regulation No. 9 of 1975 explains that the breakdown of a marriage due to divorce is the break up of a marriage because it is declared thalaq by a husband in a marriage held according to Islam. In this case, divorce is seen as the end of an unstable marriage in which the husband and wife then live separately and are officially recognized by the applicable law.

d. On the Court's decision, namely the termination of the marriage based on a court decision that has obtained permanent legal force.

Based on the current Indonesian Citizenship Law, namely Law no. 12 of 2006 concerning Citizenship of the Republic of Indonesia ("Citizenship Law"). Regarding the citizenship status in mixed marriages, this is regulated in Article 26 of the Citizenship Law, which is

reads :

a. Indonesian women who are married to men who are foreign nationals lose their citizenship of the Republic of Indonesia if according to the law of the country of origin of their husband, the nationality of the wife follows the citizenship of the husband as a result of the marriage.

b. Male Indonesian citizen who marries Foreigners lose Indonesian citizenship if the law of his country of origin, nationality husband followed his wife citizenship as a result of marriage it .

c. (2) Women as referred to in paragraph (1) or men as referred to in paragraph (2), if they wish to remain Indonesian citizens, can submit a statement letter regarding their wishes to the Officials or Representatives of the Republic of Indonesia whose territory includes the residence of the woman or man. unless the application results in dual citizenship.

d. (2) The statement letter as referred to in paragraph (3) can be submitted by the woman as referred to in paragraph (1) or by the man as referred to in paragraph (2) after 3 (three) years from the date the marriage took place.

So, if we look at the provisions of Article 26 paragraph (1) and paragraph (3) of the Citizenship Law, it can be seen that if the law of the country of origin of the husband grants citizenship to his partner due to mixed marriage, the wife who is an Indonesian citizen can lose Indonesian citizenship, unless she applies a statement to remain an Indonesian citizen and also the citizenship status of the foreign husband if the mixed marriage partner resides in Indonesia. In the provisions of the Citizenship Law, it does not specify that a foreigner who is married to an Indonesian citizen will automatically become an Indonesian citizen, including if he resides in Indonesia. The thing that the foreigner needs to pay attention to while living in Indonesia is that he must have a residence permit, if the foreigner has lived in Indonesia for 5 consecutive years or 10 consecutive years, then he or she meets the requirements to apply to become an Indonesian citizen if he wishes (see Article 9 letter $b$ of the Citizenship Law).

\section{a. Common Property Ownership According to Islamic Law}


The study of shared assets in Islamic Law is inseparable from the discussion of the concept of syirkah in marriage. Many scholars argue that joint property is included in the concept of shirkah, considering that the concept of shared assets is not found in the reference to the text of the Al-Quran and Hadith, then we can actually do it. qiyas (comparison) with the existing concept of fiqh, namely about the syirkah itself . So, it cannot be said that since the issue of shared assets is not mentioned in the Koran, the discussion of collective assets becomes far-fetched.(Susanto, 2000)

According to Yahya Harahap that the perspective of Islamic Law on the Joint Assets is in line with what was stated by Ismail Muhammad Syah in his dissertation that the search with husband and wife should be included in rub'u mu'amalah, but in fact it was not specifically discussed about this. This may be due to the fact that generally the authors of fiqh books are Arabs who do not recognize the existence of customs regarding the search with husband and wife. However, they talked about partnership which in Arabic is known as syirkah, by for search problems with a couple are included partnership, so to determine the law needs to be discussed first dahulutentang kinds of partnerships as has been discussed by the Expert Fiqh in their books.(Manan, 2006)

According to Amir Syarifuddin Islamic law regulates that the marriage agreement must be made at the time the marriage contract is carried out or afterwards and must be carried out with a special contract in the form of syirkah, if these two elements are not applied, then the personal property belonging to each husband and wife cannot be categorized as joint property. and tetapmenjadi personal property each (Manan, 2006), syirkah is a contract between people who unite in terms of capital and profit.(Sabiq, 1981)

In Islamic law there is no mixing of personal assets into the form of joint assets but it is recommended that there is mutual understanding between husband and wife in managing these personal assets, lest this management results in damage to the relationship which results in divorce, so in this case Islamic law allows for a marriage agreement before

the marriage was carried out. The agreement can be in the form of a merger of individual personal assets into joint assets, it can also be determined that there is no merger of private property into joint assets, if the agreement is made before the marriage is carried out, then the agreement is valid and must be enforced.(Manan, 2006)

Islamic law regulates a separate system between the husband's property and the wife's property as long as the person concerned does not specify otherwise (not stipulated in the marriage agreement). Islamic law also provides leeway for the two of them to make a marriage agreement according to their wishes, and the agreement finally binds them legally.

View of Islamic law that separates wealth of husband and wife actually facilitate the separation which includes treasures husband danmana which includes treasures wife, where wealth congenital the husband and where hartabawaan wife before marriage, where the treasures were acquired husband and treasure acquired wives individually during marriage, as well as which joint assets are obtained collectively during the marriage. This separation will be very useful in separating the husband's assets and the wife's assets in case of divorce in their marriage. The provisions of Islamic law remain in effect until the end of the marriage or one of the two dies.

Based on the results of interviews with a resource person who conducted a mixed marriage, namely a woman with the initials $\mathrm{T}$ who works as an employee at the 
Gorontalo State University, Faculty of sports and health, which researchers interviewed on Tuesday, January 28, 2018 at the Sports and Health Faculty at 03.00 This has been married to foreign citizens of African nationality 7 years ago in Indonesia. Marriage between Indonesian citizens and foreigners in Indonesian law is referred to as mixed marriage, which is a marriage between two people who in Indonesia are subject to different laws due to differences in nationality and one of them is an Indonesian citizen (Article 57 UUP). Because this marriage is carried out in Indonesia, in a mixed marriage, one of the parties can obtain the citizenship of the husband / wife and can also lose his citizenship according to the methods specified in the applicable Indonesian Citizenship Law.

Their marriage was blessed with 1 son. ex-husband who had the initials $\mathbf{J}$ works as a football player in Indonesia, before he died he had several times to strengthen the team football persigo (Football Association gorontalo ) After he died he left a fortune in money of 90 million which has not been melted by the PSSI, mobi , 1 and houses and land. However, in this division, of course, must follow. In such cases, the settlement / distribution is adjusted to the contents of the agreement and the propriety

applies .

The point of the problem in the occurrence of a divorce is joint property. The Marriage Law (Article 37) only states that if the marriage breaks up due to divorce, joint assets are regulated according to their respective laws. In the elucidation of the article, it is stated that what is meant by "the law" is religious law, customary law, and other laws . If we look at the legal system as mentioned earlier, the settlement for joint property can be determined as follows: For those who are married according to Islam, it must be distributed based on the compilation of Islamic law, whereas Islamic law does not recognize joint property as well as positive Indonesian law. in Article Article 21 paragraph (1) LoGA only Indonesian citizen (citizen) who may have owned.

So if referring to this legal basis, the legal consequences of marriage that occur above can be said that mixed marriage will bring legal consequences to the parties who do it, as well as Mixed Marriage. As for the legal consequences of Mixed Marriages relating to the nationality of the spouse, the citizenship of the child, and the assets in marriage, especially the ownership of immovable property in the form of land, because according to Law number 5 of 1960 on Agrarian Principles it is stated that, only Indonesian citizens who can have freehold rights over land. For Indonesian citizens who are married to foreign citizens, it will be difficult to own land or buildings with Hak Milik status .

This is because the Indonesian Marriage Law stipulates that property acquired during marriage becomes joint property, where both parties have the same rights over the property. Meanwhile, the Basic Agrarian Law states that foreign citizens cannot own land with freehold status. The problem that often arises is when there is a divorce, either a divorce or a divorce in a mixed marriage, and one of the parties demands that the distribution of the property is gono gini. So the wife is treated as stipulated in Article 21 of the Basic Agrarian Law, she is equalized with a foreigner, that is, she cannot have property rights, if she gets a gift or will during the marriage, then she must give up her rights or reduce the status of her land to Right to Use. To overcome this, it is better if a Marriage Agreement is made at the time or before the marriage takes place, to avoid mixing of assets between the wife's assets and the husband's assets. The Marriage Agreement must be made before a Notary Public and must not conflict with the Law. 
In the distribution of joint assets, there are factors or obstacles faced by everyone who engages in a mixed marriage. There are several problems related to the sharing of assets together. Problems arise related to the distribution of joint assets in the form of movable and immovable objects. Regarding immovable objects, the problem lies with the ownership status in the event of a divorce. Another problem is related to which law will be used in the distribution of the joint assets. The sources and types of legal materials used are primary legal materials supported by secondary legal materials. Primary legal materials are obtained from statutory documents related to this research, while secondary legal materials are obtained from books, journals, relevant scientific works and other legal materials. In analyzing the data have been obtained by means of classifying materials primary law and secondary later analysis using methods of interpretation or interpretation, so as to explain the existing problems more

detail .

In terms of its object, this regulation needs to be revised again because this is a discrimination against foreigners / Indonesians and needs reinterpretation and socialization of society .

a. In terms of the subject, there must be a regulation prohibiting that Indonesian citizens are not allowed to continue marriage with foreigners, so that the existing rules in Indonesia and also in the Compilation of Islamic Law continue to run.

b. In terms of the subject, there must be a regulation prohibiting that Indonesian citizens are not allowed to marry foreigners, so that the existing rules in Indonesia and also in the complications of Islamic law continue to run.

\section{Conclusion}

The mechanism of mixed marriage between Indonesian citizens and foreigners in Indonesia, namely: 1) Mixed Marriage Marriage between two people ; 2) Indonesia is subject to a different law; 3) In accordance with the Applicable Law u; 4) Certificate from Employee of Marriage Registrar; 5) The papers to be prepared . The regulation regarding the distribution of joint assets in mixed marriages according to Law Number 5 of 1960 concerning Agrarian Principles states that only Indonesian citizens can own ownership rights over land. For Indonesian citizens who are married to foreign citizens, it will be difficult to own land or buildings with Hak Milik status. This relates to the nationality of the spouse, the nationality of the child, and the assets in marriage, especially the ownership of immovable property in the form of land.

\section{References}

Achmad, M. F. dan Y. (n.d.). Dualisme Penelitian Hukum Normatif dan Empiris. Yogyakarta: Pustaka Belajar.

Darmabrata, W. (2004). Hukum Perkawinan dan Keluarga di Indonesia. Jakarta: FH UI.

Indonesia, P. (n.d.). Bedah Kasus Penetapan Pengadilan Atas Pisah Harta Setelah Berlangsungnya Perkawinan Bagi Pelaku Perkawinan Campuran di Indonesia: Tinjauan Hukum Terhadap Status Kepemilikan Properti.

Manan, A. (2006). Aneka Masalah Hukum Perdata Islam di Indonesia. Jakarta: Prenada 
Media Group.

Marzuki, P. M. (2010). Penelitian Hukum. Yogyakarta: Pustaka Pelajar.

Ratulangi, U. S. (n.d.). Peraturan Tentang Perkawinan Campuran (Penetapan Raja). Retrieved from http://hukum.unsrat.ac.id/uu/s1898 158

Sabiq, S. (1981). Fiqh al-sunnah jilid 13. Bandung.

Susanto, H. (2000). Pembagian Harta Gono-Gini Setelah Terjadinya Perceraian. Jakarta: Bulan Bintang.

Tutik, T. T. (2006). Pokok-Pokok Hukum Tata Negara. Jakarta: Pustaka Publisher.

Undang-Undang Nomor 12 Tahun 2006.

Undang-Undang Nomor 5 Tahun 1960 tentang Peraturan-Peraturan Dasar Pokok Agraria.

UU Nomor 1 Tahun 1974 Tentang Perkawinan. 